UDK $630 * 92(4)$

\title{
PRIVATE FOREST OWNERS IN SELECTED SOUTH-EAST EUROPEAN COUNTRIES: IN SEARCHING FOR INFORMATION
}

\author{
Vlasnici privatnih šuma u izabranim državama jugoistočne Evrope: u potrazi za \\ informacijama
}

Mersudin Avdibegović ${ }^{1}$, Nenad Petrović ${ }^{2}$, Stjepan Posavec ${ }^{3}$, Špela Pezdevšek Malovrh ${ }^{4}$

\begin{abstract}
Social, economical and political changes in South-east European countries have led to significant shift from traditional pattern of forest policy to new, more complex paradigm when it comes to forestry and forest resources management. Among other things, this implies increasing of private forest owners' heterogeneity which is reflected in changes of their expectations, objectives, attitudes and management practices. In this context, it is important to explore how private forest owners obtain information useful for forest management but also to analyze in which way their characteristics influence fulfilling of informational needs. The objective of this paper was to analyse sources of information that private forest owners are most likely to use, and to assess how owners' characteristics, property conditions as well as management behaviour, affect it. Surveys were conducted in Bosnia-Herzegovina $(n=350)$, Serbia $(n=350)$, Croatia $(n=350)$ and Slovenia $(n=322)$ on random samples of private forest owners while the data were analysed by using logistic regression model. The paper examined five models of information providers: private forest owners associations (1), relatives (2), public forest administration (3), other owners (4) and public forest companies (5). Comparison between countries indicates the differences regarding to informational providers, caused mainly due to importance of private forests to their owners and different organizational structure of national forest sectors. Comparing to other countries, it seems that Slovenian private forest owners are more active in searching for information. Public forest administration is the most preferable provider of information in Slovenia while in Bosnia-Herzegovina these are public forest companies and public forest administration. In Serbia and Croatia the most common providers of information are public forest companies. Only Slovenian private forest owners use interest associations as the source of information. The traditional providers
\end{abstract}

\footnotetext{
${ }^{1}$ University of Sarajevo, Faculty of Forestry

${ }^{2}$ University of Belgrade, Faculty of Forestry

${ }^{3}$ University of Zagreb, Faculty of Forestry

${ }^{4}$ University of Ljubljana, Biotechnical Faculty
} 
of information (other owners) are still important for private forest owners in Slovenia and Bosnia-Herzegovina at least. The results of logistic regression models reveal that forest property size, fragmentation, harvesting activities as well as owners' age influence the source of information that private forest owners are most likely to use. The model 3 (pubic forest administration) is statistically significant in Slovenia and Bosnia-Herzegovina, while in Serbia and Bosnia-Herzegovina the model 5 (public forest company) is significant. None of the models is statistically significant for Croatia. Besides, the model 4 (other owners) was statistically significant in Slovenia.

Key words: Private forest owners, Information, Forest policy, South-east European countries.

\section{INTRODUCTION - Uvod}

Based on differences in the proportion of private forests, Bosnia-Herzegovina, Serbia, Croatia and Slovenia vary significantly in terms of the role of private forest owners in national forest policy and importance of private forests for national economy (PEZDEVŠEK MALOVRH et al., 2011). While in Slovenia, private forest owners posses a largest share of the country's forests (76\%) in Bosnia-Herzegovina and Croatia private forests occupy roughly $20 \%$ of all forests. In Serbia, private forests cover approximately $47 \%$ of the total forest area (BANKOVIĆ, 2009). Nevertheless, forest ownership pattern is quite similar in all Western Balkan countries and characterizing by small-scale and fragmented individual property in average (GLÜCK et al., 2011).

Growing diversity of private forest owners across Europe (SCHMITHÜSEN AND HIRSCH, 2010; ŽIVOJINOVIĆ et al., 2015) is accompanied by changes in forest owners' objectives (KUULUVAINEN et al., 1996; KARPPINEN, 1998; HOGL et al., 2005; VIERSUM et al., 2005; NI DHUBHÁIN et al., 2007), attitudes (BOON AND MEILBY, 2007), and management practices (EMTAGE et al., 2007; NI DHUBHAIN et al., 2010), influencing the informational needs of private forest owners. Different groups of private forest owners (BOON et al., 2004; ZIEGENSPECK et al., 2004; NI DHUBHÁIN et al.,2007; PEZDEVŠEK MALOVRH et al., 2015) may require different kind of information (FINLEY et al., 2006), in different forms (HUJALA AND TIKKANEN, 2008; HAMUNEN et al., 2014) and from different sources (LONNSTEDT, 1997). HUJALA and TIKKANEN pointed out that trust in accepted advisors, positive previous experiences, sense of fellowship and tailored customer care, appear to be essential ingredients of smooth communication in owners' decision making. The results of their research also refer to a preference for live communication over internet-mediated communication. On the other hand, HAMUNEN et al. believe that forest owners' peer-to-peer learning cannot replace the guidance given by forest professionals. According to him, it can support and complement the prevailing extension practices, only when the aim is to engage, inform and inspire forest owners. The results of Lonnstedt's research on goals, opportunities and alternatives of non- 
industrial private forest owners, show that an active owner want to make the decision on whether to cut or not by himself or herself. However, the identification of an opportunity to cut could be made by someone else. Forest owners may also consult people close by to confirm their decision to cut. The need for more information before starting with management activities is a frequent theme in many studies of private forest owners (FINLEY et al. 2006) and there is only a small group of owners who are not interested in more information. Therefore, communicating with private forest owners and understanding how they obtain information has become a growing challenge for both, public forest administration and forest policy makers. Previous researches have indicated that private forest owners may get at least as much information and advice on forest management from neighbours, friends and other owners peers, as from professional foresters employed with public forest administration (SCHUBERT AND MAYER, 2012; HAMUNEN et al., 2014). Moreover, advices about forest management from neighbours, friends and family members are applied more often than those obtained from experts (RICKENBACH et al., 2005; MA et al., 2012; SCHUBERT AND MAYER, 2012).

Sustainable forest management, as an ultimate goal of any national forest policy cannot be ensured without appropriate mix of policy instruments. Among several informational instruments of forest policy, different types of support to private forest owners (i.e. free of charge extension service usually offered by public forest administration as leading actor of forest policy in post-socialism countries) are frequently in use. In four analyzed countries, either public forest administration or public forest companies traditionally use different ways to provide useful information to private forest owners (i.e. organization of educational programmes and training, financing professional excursions in order to support knowledge exchange, publishing information and articles on forest-related issues in professional journals and local press etc.). Still, the information about forest management is often served to private forest owners through their personal contact with forestry professionals on site.

When it comes to four analyzed countries, several types of private forest owners alliances (e.g. associations, machinery rings) have existed only in Slovenia in the nineties of XX century. At the beginning of 2000s in other countries, private forest owners associations (hereinafter: PFOAs) were established with more or less success. Based on previous positive experiences, in Slovenia these associations become important actor of forest policy and active provider of information for private forest owners. By organizing seminars, field excursions, timber sale auctions and similar events, PFOAs are sharing information related to forest management and timber market. Besides, PFOAs facilitate efforts of private forest owners to apply for supporting projects offered by several institutions. Although there are many preconditions for successful existence of such interest associations, majority of private forest owners in Serbia and Bosnia-Herzegovina are not actively involved in creation of PFOAS. Even in Slovenia, only 1\% of private forest owners are currently engaged in PFOAs (PEZDEVŠEK MALOVRH et al., 2010; LEBAN, 2014). 
There is a variety of information to encourage sustainable management of private forest, created by different providers in different forms. The study dealing with several sources of information for private forest owners in Slovenia and BosniaHerzegovina (the results of this study are integrated in this paper) has been conducted recently (AVDIBEGOVIĆ AND PEZDEVŠEK MALOVRH, 2015), but from the perspective of private forest owners in the region, it still remains unclear what is the most preferable way of obtaining information related to private forest management.

The aim of this paper was to a) analyse sources of information that private forest owners are most likely to use in Bosnia-Herzegovina, Serbia, Croatia and Slovenia, and b) develop an econometric model to assess how private forest owners' characteristics like socio-demographic characteristics, property conditions and management behaviour affect what source of information private forest owners are most likely to use. The findings of this paper may help to policy decision makers to create an appropriate mix of forest policy instruments to improve state of the art when it comes to private forests in analyzed countries.

\section{MATERIAL AND METHODS - Materijal i metode}

Similar surveys were conducted to private forest owners in all four countries with some variations related to country-specific conditions in private forests. The examinees (private forest owners) have been asked about a range of issues related to their socio-demographic characteristics, forest features, management behaviour and informational sources. The data were obtained from face-to-face interviews with randomly selected private forest owners. A systematic random sample was developed for the entire private forest owner population of Slovenia. The owners were divided in strata according to property size (less than 0.99 ha, $1-4.99$ ha, 5 - 9.99 ha, $10-29.99$ ha, and more than $30 \mathrm{ha}$ ) following the classification used in forest management plans. Within each stratum, owners were divided into two equally sized groups: members and non-members of interest associations. The questionnaire was pre-tested in 2008 and the survey was conducted from May 2008 through May 2009. The sample used in the analyses consisted of 322 owners for a response rate of $46.6 \%$ (PEZDEVŠEK MALOVRH, 2010). In order to investigate the informational sources of private forest owners in Bosnia - Herzegovina, Croatia and Serbia, sampling approach was used from PRIFORT ${ }^{5}$ project (GLÜCK et al., 2010; GLÜCK et al., 2011). The random sample for the door-to-door survey was drawn from overlapping regions with the highest percentage of forest areas and the largest share of private forests. All municipalities in these regions were ranked by these two criteria, and the most representative ones within each country were selected. In order to identify 350 interviewees per country, the list of all local communities (settlements), within

\footnotetext{
5 PRIFORT project (research into organization of private forest owners in the Western Balkans) was financed by the
} Ministry of Agriculture, Forestry, Environment and Water Management of the Republic of Austria 
selected municipalities was created. In total, 35 settlements were randomly chosen from this list. In order to contact 10 owners in each settlement (once they were randomly selected), close cooperation with forest guards employed with public forest administration was established. For Bosnia-Herzegovina, the questionnaire was pretested in March 2008 and the survey was conducted in May and June 2008. For Serbia and Croatia, the questionnaires were pre-tested in May 2012 and the survey data were collected within WESPROFOR ${ }^{6}$ project (May-December 2012).

All data from surveys were summarized by frequency distributions. A multivariate logistic regression (logit models) (HOSMER AND LEMESHOW, 2000) was applied to assess how certain socio-demographic characteristics, property conditions and management behaviour influence what informational source private forest owners are likely to use by means of the Enter algorithm (FIELD, 2009). The dependent variable, "information providers" were divided into five categories: private forest owners associations (1), relatives (2), public forest administration (3), other owners (4) and public forest companies (5). It is important to underline that WESPROFOR questionnaire did not include two categories as possible answers (public forest administration and other owners) so in case of Serbia and Croatia, the data related to these two categories, as possible providers of information, are missing. The dependent variable is coded as "0" for not receiving information and " 1 " for receiving information. Separate logistic regression analyses were conducted for each dependent variable. The independent variables in Table 1 were evaluated in logit models.

Table 1: Independent variables used in logistic regression models Tabela 1. Nezavisne varijable korištene u modelima logističke regresije

\begin{tabular}{|l|l|}
\hline \multicolumn{1}{|c|}{ Variable } & \multicolumn{1}{c|}{ Categories } \\
\hline Gender & Male, Female \\
\hline Age & Less than 65 years, More than 65 years \\
\hline Education & $\begin{array}{l}\text { Less than high school education, High school education or } \\
\text { more }\end{array}$ \\
\hline Forest property size & Less than 1 ha, More than 1 ha \\
\hline Fragmentation & Consolidate, Fragmented \\
\hline Harvesting activities & Harvest, Do not harvest \\
\hline
\end{tabular}

Before running the analysis, the data were assessed for multicollinearity, using variation inflation factors (VIFs), which ensure that no high correlations exist when one independent variable is regressed on the other (FIELD, 2009). The results of the diagnostics revealed that collinearity was not significant (no VIF exceeded 5). All statistical analyses were carried out using SPSS 21 software (Corp. 2011).

\footnotetext{
${ }^{6}$ WESPROFOR project (Opportunities for wood energy production from small-scale forests in the South Eastern Europe Region) was a part of FOPER project, financed by the Ministry of Foreign Affairs of Finland and coordinated by the European Forest Institute (EFI)
} 


\section{RESULTS AND DISCUSSION - Rezultati i diskusija}

To determine informational sources that private forest owners are most likely to use, respondents in all four countries were asked where they obtained information related to forest management. Multiple answers were obtained (Figure 1).

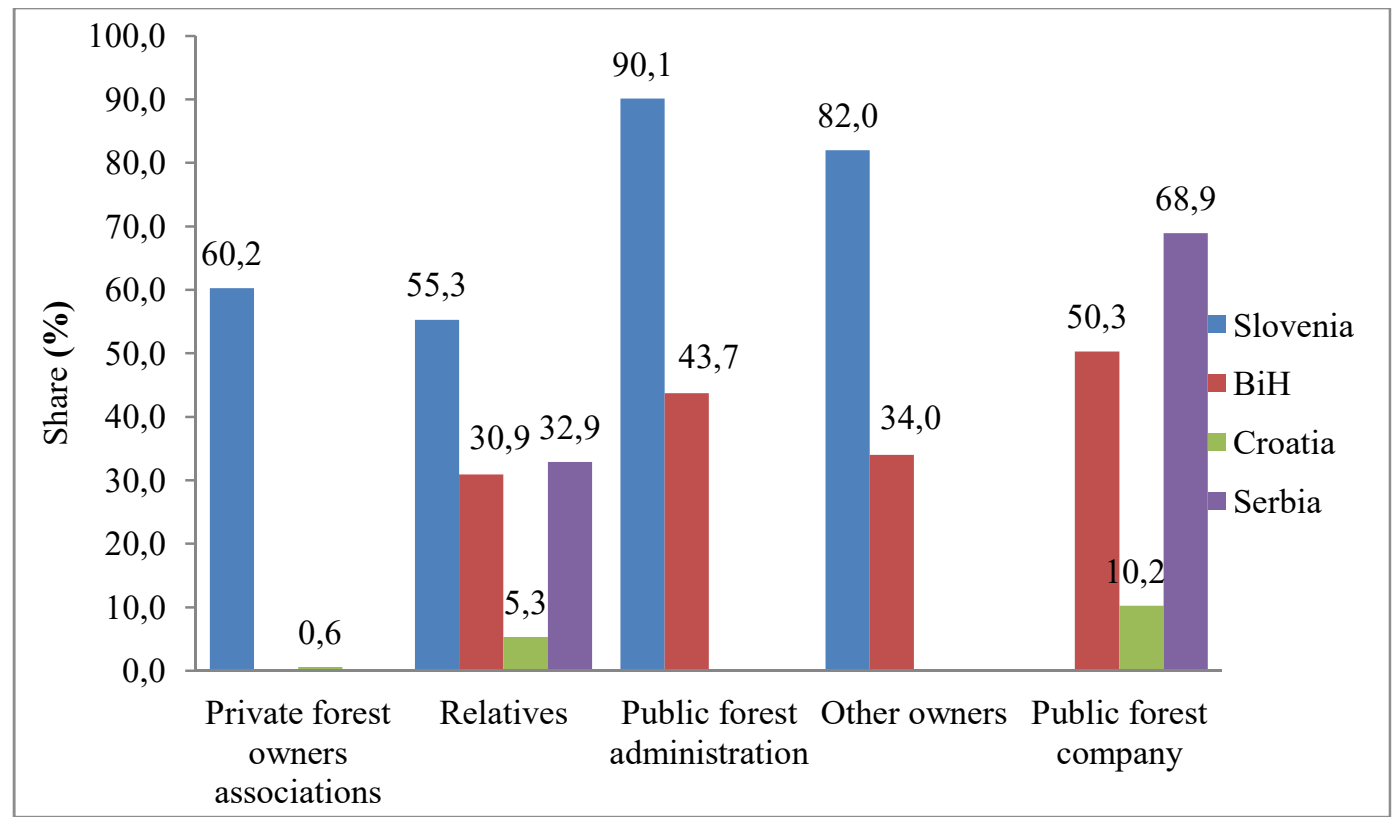

Figure 1. Sources of information for private forest owners

Slika 1. Izvori informacija za vlasnike privatnih šuma

The results from Figure 1 show that the most common source of information in all countries are either public forest administration (Bosnia-Herzegovina and Slovenia) or public forest companies (Bosnia-Herzegovina, Serbia and Croatia). However, the most frequent informational source varies within countries. Apart of public forest administration, Slovenian private forest owners use also other owners $(82,0 \%)$, PFOAs $(60,2 \%)$ and relatives $(55,3 \%)$ as sources of information. These findings can be explained by existing of traditionally powerful and well organized public forest administration in Slovenia where recently established PFOAs, other owners and relatives are used as additional sources of information, in case when some information are not provided by public forestry administration. Having in mind the fact that PFOAs in Bosnia-Herzegovina are either rare or inactive, the most common sources of information (apart from public forest company and public forest administration) are other private forest owners $(34,0 \%)$ and relatives $(30,9 \%)$. Historical and political conditions that shaped forest ownership pattern in Bosnia- 
Herzegovina, Croatia and Serbia in the past, led to the situation that private forests hardly can be compared with state-owned forests in terms of volume, increment and health conditions. Private forests are frequently fragmented and rather small-scale to the extent they have been treated as "second" forests during the period of socialism, by both public forest administration but also private forest owners. Besides, bad collective memory on the period of socialism is still reflecting on private forest owners' attitudes towards state authorities. The consequence is that private forest owners mainly expressed low interest for any kind of information. This holds particularly for Croatia. As organisational structure of forest sectors in Serbia and Croatia assigns all issues regarding private forests to public forest companies, it is logical that forest professionals employed within companies are the most frequent address for private forest owners when they need any kind of information. Situation may be changed in Croatia recently where the Forest Advisory Service was established within the Ministry of Agriculture since 2015.

The results of the logistic regression models reflecting sources of information that private forest owner's use are presented in Table 2 for Slovenia, Table 3 for Bosnia-Herzegovina, Table 4 for Serbia and Table 5 for Croatia. Two models were statistically significant in Slovenia: Model 3 (public forest administration, correctly predicted 90,1\%) and Model 4 (other owners, correctly predicted 81,8\%). Model 3 (public forest administration, correctly predicted 63,7\%) was statistically significant in Bosnia-Herzegovina as well as Model 5 (public forest company, correctly predicted $61,9 \%$ ). In Serbia it was also Model 5 (public forest company, correctly predicted $70,5 \%$ ) while none of models were statistically significant in Croatia.

Results of Model 3 for Slovenia reveal that private forest owners who do not harvest timber from their forest were more likely to request information from public forest administration than owners who manage their forest actively. Those owners who do not harvest timber have less experience in forest operations and that's why they search for forest management information more often. The Model 4 in Slovenia indicates that owners who have consolidated forest property were more likely to have used information from other owners. In case of consolidated property, forest management is most cost-effective which is the factor that induce private forest owners to coordinate their interests and thus to communicate with the neighbouring owners. Besides, owners younger than 65 years are more likely to have used information from other owners than those who are elder. This shows that younger owners are more active in searching for information and thus more independent in decision making. 
Table 2: Results of binary logistic regression for Slovenia

Tabela 2. Rezultati binarne logističke regresije za Sloveniju

\begin{tabular}{|c|c|c|c|c|}
\hline \multirow[t]{2}{*}{ Variables } & $\begin{array}{c}\text { Model } 1 \\
\text { PFOAs }\end{array}$ & $\begin{array}{c}\text { Model } 2 \\
\text { Relatives }\end{array}$ & $\begin{array}{c}\text { Model 3 } \\
\text { Public forest } \\
\text { administration }\end{array}$ & $\begin{array}{c}\text { Model } 4 \\
\text { Other } \\
\text { owners }\end{array}$ \\
\hline & \multicolumn{4}{|c|}{ Coefficient Exp (B) } \\
\hline Constant & - & - & 2,189 & 1,659 \\
\hline \multicolumn{5}{|l|}{ Gender } \\
\hline Female & - & - & 2,346 & 0,919 \\
\hline Male & 1,000 & 1,000 & 1,000 & 1,000 \\
\hline \multicolumn{5}{|l|}{ Age } \\
\hline Less than 65 & - & - & 2,134 & $2,081 * *$ \\
\hline More than 65 & 1,000 & 1,000 & 1,000 & 1,000 \\
\hline \multicolumn{5}{|l|}{ Education } \\
\hline Less than high school & - & - & 0,943 & 1,550 \\
\hline More than high school & 1,000 & 1,000 & 1,000 & 1,000 \\
\hline \multicolumn{5}{|l|}{ Forest property size } \\
\hline Less than 1 ha & - & - & 1,209 & 0,648 \\
\hline More than 1 ha & 1,000 & 1,000 & 1,000 & 1,000 \\
\hline \multicolumn{5}{|l|}{ Fragmentation } \\
\hline Consolidate & - & - & 2,496 & $3,109 * *$ \\
\hline Fragmented & 1,000 & 1,000 & 1,000 & 1,000 \\
\hline \multicolumn{5}{|l|}{ Harvesting } \\
\hline Do not harvest & - & - & $2,189 * *$ & 15,332 \\
\hline Harvest & 1,000 & 1,000 & 1,000 & 1,000 \\
\hline$\chi^{2}$ & 10,367 & 10,026 & 13,539 & 15,332 \\
\hline p value & 0,110 & 0,124 & 0,035 & 0,018 \\
\hline $\begin{array}{l}\text { Observations correctly } \\
\text { predicted }(\%)\end{array}$ & - & - & 90,1 & 81,8 \\
\hline
\end{tabular}

$* *$ Variables are significant at $\mathrm{p}<0,05 ; * * *$ Variables are significant at $\mathrm{p}<0,001$

Results of Model 3 in Bosnia-Herzegovina pointed out that owners with less than 1 ha of forest were more likely to ask for information from public forest administration comparing to those with more than 1 ha. There are no many private forest owners that belong to the second category (possessing more than $1 \mathrm{ha}$ ) and these are mainly people with substantial traditional skills and basic equipment when it comes to wood harvesting, transport and selling to local market. The most common product is fuel wood for their own use and in reality they do not need any additional information regarding their forests. Those with less than 1 ha probably do not have enough knowledge what to do with their forests and this is the reason why they are more active in searching for information. The finding that owners who do not harvest their forest were less likely to have used information from public forest administration can be explained by the absence of any interests to manage private forests. Significant 
portion of private forest owners in Bosnia-Herzegovina do not harvest their forests because they are too small, fragmented and thus non cost-effective for managing. This is the reason why they do not ask any institution (including public forest administration) for any kind of advice, support or information.

The results of Model 5 pointed out that owners with less than 1 ha of forest were more likely to have use information from public forest company than those with more than 1 ha. It can be explained by lack of experience and professional knowledge as it was in Model 3. Besides, owners with consolidated forest property were less likely to ask information from public forest company comparing to those with fragmented property. Again, these are mainly people from rural areas that traditionally manage their forests for fuel wood production (for domestic consumption) and not for selling. Thus, they do not need specific information regarding their forests. Eventually, the results of Model 5 show that owners who do not harvest timber are more likely to request information from public forest company than those who harvest timber more regularly. It can be explained by lack of experiences in forest operations and stronger need for information related to forest management. However, it is in contrary to the findings of Model 3 and can be explained only by the fact that private forestry issues in Bosnia-Herzegovina are separately organized in two entities. While in the Republic of Srpska, public forest company is administratively in charge for all professional issues in private forests (the similar organizational model like in Serbia), in the Federation of Bosnia-Herzegovina these tasks are entrusted to public forest administration at cantonal levels. As the data obtained from interviews with private forest owners are not separated per entities, the results of Model 3 and Model 5 are controversial. The fact that two entities have different organizational set-up when it comes to forest sector, with different role of forest policy actors, has to be considered in similar research. 
Table 3: Results of binary logistic regression for Bosnia-Herzegovina

Tabela 3. Rezultati binarne logističke regresije za Bosnu i Hercegovinu

\begin{tabular}{|c|c|c|c|c|c|}
\hline \multirow[t]{2}{*}{ Variables } & $\begin{array}{l}\text { Model } 1 \\
\text { PFOAs }\end{array}$ & $\begin{array}{l}\text { Model } 2 \\
\text { Relatives }\end{array}$ & $\begin{array}{c}\text { Model } 3 \\
\text { Public forest } \\
\text { administration }\end{array}$ & $\begin{array}{l}\text { Model } 4 \\
\text { Other } \\
\text { owners }\end{array}$ & $\begin{array}{c}\text { Model 5 } \\
\text { Public } \\
\text { forest } \\
\text { company } \\
\end{array}$ \\
\hline & \multicolumn{5}{|c|}{ Coefficient $-\operatorname{Exp}(B)$} \\
\hline Constant & - & - & 0,275 & - & 0,664 \\
\hline \multicolumn{6}{|l|}{ Gender } \\
\hline Female & - & - & 1,349 & - & 0,777 \\
\hline Male & 1,000 & 1,000 & 1,000 & 1,000 & 1,000 \\
\hline \multicolumn{6}{|l|}{ Age } \\
\hline Less than 65 & - & - & 1,719 & - & 0,890 \\
\hline More than 65 & 1,000 & 1,000 & 1,000 & 1,000 & 1,000 \\
\hline \multicolumn{6}{|l|}{ Education } \\
\hline $\begin{array}{l}\text { Less than high } \\
\text { school }\end{array}$ & - & - & 1,134 & - & 1,250 \\
\hline $\begin{array}{l}\text { More than high } \\
\text { school }\end{array}$ & 1,000 & 1,000 & 1,000 & 1,000 & 1,000 \\
\hline \multicolumn{6}{|l|}{$\begin{array}{l}\text { Forest property } \\
\text { size }\end{array}$} \\
\hline Less than 1 ha & - & - & $2,220 * *$ & - & $1,897 * *$ \\
\hline More than 1 ha & 1,000 & 1,000 & 1,000 & 1,000 & 1,000 \\
\hline \multicolumn{6}{|l|}{ Fragmentation } \\
\hline Consolidate & - & - & 1,595 & - & $0,543 * *$ \\
\hline Fragmented & 1,000 & 1,000 & 1,000 & 1,000 & 1,000 \\
\hline \multicolumn{6}{|l|}{ Harvesting } \\
\hline Do not harvest & - & - & $0,292 * *$ & - & $3,224 * *$ \\
\hline Harvest & 1,000 & 1,000 & 1,000 & 1,000 & 1,000 \\
\hline$\chi^{2}$ & 9,625 & 9,031 & 33,258 & 7,934 & 18,818 \\
\hline p value & 0,324 & 0,172 & 0,000 & 0,243 & 0,04 \\
\hline $\begin{array}{l}\text { Observations } \\
\text { correctly } \\
\text { predicted (\%) }\end{array}$ & - & - & 63,7 & - & 61,9 \\
\hline
\end{tabular}

$* *$ Variables are significant at $\mathrm{p}<0,05 ; * * *$ Variables are significant at $\mathrm{p}<0,001$

Results of Model 5 for Serbia reveal that private forest owners who do not harvest timber from their forest were less likely to used information from public forest company than those who manage their forest. Due to specific forest ownership pattern in Serbia where private forest lots are small and fragmented, many forest owners do not manage their property actively. These forests are in many cases coppice and owners use them mostly for own fuel wood production. Information related to forest management are mostly transferred to private forest owners by their ancestors and 
that's why they do not have a need to request information from any institution, including advisory service offered by public forest company.

Table 4: Results of binary logistic regression for Serbia Tabela 4. Rezultati binarne logističke regresije za Srbiju

\begin{tabular}{|c|c|c|c|}
\hline \multirow[t]{2}{*}{ Variables } & $\begin{array}{l}\text { Model } 1 \\
\text { PFOAs }\end{array}$ & $\begin{array}{c}\text { Model } 2 \\
\text { Relatives }\end{array}$ & $\begin{array}{c}\text { Model } 5 \\
\text { Public forest } \\
\text { company }\end{array}$ \\
\hline & \multicolumn{3}{|c|}{ Coefficient - Exp (B) } \\
\hline Constant & - & - & 2,211 \\
\hline \multicolumn{4}{|l|}{ Gender } \\
\hline Female & - & - & 1,087 \\
\hline Male & 1,000 & 1,000 & 1,000 \\
\hline \multicolumn{4}{|l|}{ Age } \\
\hline Less than 65 & - & - & 1,696 \\
\hline More than 65 & 1,000 & 1,000 & 1,000 \\
\hline \multicolumn{4}{|l|}{ Education } \\
\hline Less than high school & - & - & 0,863 \\
\hline More than high school & 1,000 & 1,000 & 1,000 \\
\hline \multicolumn{4}{|l|}{ Forest property size } \\
\hline Less than 1 ha & - & - & 0,616 \\
\hline More than 1 ha & 1,000 & 1,000 & 1,000 \\
\hline \multicolumn{4}{|l|}{ Fragmentation } \\
\hline Consolidate & - & - & 0,769 \\
\hline Fragmented & 1,000 & 1,000 & 1,000 \\
\hline \multicolumn{4}{|l|}{ Harvesting } \\
\hline Do not harvest & - & - & $0,473^{* *}$ \\
\hline Harvest & 1,000 & 1,000 & 1,000 \\
\hline$\chi^{2}$ & 6,327 & 5,090 & 13,107 \\
\hline p value & 0,432 & 0,532 & 0,041 \\
\hline $\begin{array}{l}\text { Observations } \\
\text { correctly predicted } \\
(\%)\end{array}$ & - & - & 70,5 \\
\hline
\end{tabular}

$* *$ Variables are significant at $\mathrm{p}<0,05 ; * * *$ Variables are significant at $\mathrm{p}<0,001$

The results of the logistic regression for Croatia show that private forest owners' socio-demographic characteristics, their property conditions and management behaviour do not influence independent variable (informational source they are likely to use) to the extent to identify any statistically significant model. It can be concluded that management information are not important to private forest owners so usually they manage forests based on their own experiences and needs. As the response rate on the question where private forest owners from Croatia obtained information related 
to forest management was very low, any model could be identified as statistically significant.

Table 5: Results of binary logistic regression for Croatia

Tabela 5. Rezultati binarne logističke regresije za Hrvatsku

\begin{tabular}{|c|c|c|c|}
\hline \multirow[t]{2}{*}{ Variables } & $\begin{array}{l}\text { Model } 1 \\
\text { PFOAs }\end{array}$ & $\begin{array}{c}\text { Model } 2 \\
\text { Relatives }\end{array}$ & $\begin{array}{c}\text { Model 5 } \\
\text { Public forest } \\
\text { company } \\
\end{array}$ \\
\hline & \multicolumn{3}{|c|}{ Coefficient - Exp (B) } \\
\hline Constant & - & - & - \\
\hline \multicolumn{4}{|l|}{ Gender } \\
\hline Female & - & - & - \\
\hline Male & 1,000 & 1,000 & 1,000 \\
\hline \multicolumn{4}{|l|}{ Age } \\
\hline Less than 65 & - & - & - \\
\hline More than 65 & 1,000 & 1,000 & 1,000 \\
\hline \multicolumn{4}{|l|}{ Education } \\
\hline Less than high school & - & - & - \\
\hline More than high school & 1,000 & 1,000 & 1,000 \\
\hline \multicolumn{4}{|l|}{ Forest property size } \\
\hline Less than 1 ha & - & - & - \\
\hline More than 1 ha & 1,000 & 1,000 & 1,000 \\
\hline \multicolumn{4}{|l|}{ Fragmentation } \\
\hline Consolidate & - & - & \\
\hline Fragmented & 1,000 & 1,000 & 1,000 \\
\hline \multicolumn{4}{|l|}{ Harvesting } \\
\hline Do not harvest & - & - & - \\
\hline Harvest & 1,000 & 1,000 & 1,000 \\
\hline$\chi^{2}$ & 6,437 & 7,072 & 10,598 \\
\hline p value & 0,467 & 0,529 & 0,226 \\
\hline $\begin{array}{l}\text { Observations } \\
\text { correctly predicted } \\
(\%)\end{array}$ & - & - & - \\
\hline
\end{tabular}

** Variables are significant at $\mathrm{p}<0,05 ; * * *$ Variables are significant at $\mathrm{p}<0,001$

\section{CONCLUSIONS - Zaključci}

As private forest owners are a diverse group of individuals with different attitudes, management objectives and practices, better understanding on how they obtain information regarding forest management is very important for public forest administration and key national policy makers. The results of this research offer useful insights into sources and providers of information that private forest owners in Bosnia- 
Herzegovina, Serbia, Croatia and Slovenia are most likely to use. Moreover, it provides the logistic regression models to understand how private forest owners' characteristics affect what source of information private forest owners are most likely to use. It is clear that the role of the public forest administration and public forest companies in delivering information to private forest owners is crucial. Private forests are fragmented and small-scale to the extent that negatively affects economic interests of majority of private forest owners for active forest management. Private forests hardly can be managed in a sustainable way without strong support of public forest service in financial and professional terms. This is the main reason why public forest administration and public forest companies traditionally have held a strong position in the eyes of private forest owners. However, other providers of information, such as relatives and neighbouring must not be neglected. There is a big potential in private forest owners' associations as a provider of information for private forest owners. The results of previous research (FOPER project) pointed out to a critical mass of private forest owners who are ready to engage themselves in the establishment of such associations. Regardless these associations are created voluntary or compulsory, they would increase political influence of private forest owners and better promote their interests. Starting from the assumption that private forest owners are not homogenous group, public forest service should try to develop and implement a mix of forest policy to target specific interests of several types of private forest owners. As informational instruments are not strongly developed in analyzed countries (Slovenia may be an exception from this pattern), there is a room to improve overall national forest policies by developing innovative approaches (such as extension service, machinery rings, training etc.) that will better satisfy specific private forest owners' needs for information.

\section{REFERENCES - Literatura}

AVDIBEGOVIĆ, M., PEZDEVŠEK MALOVRH, Š. (2015): Sources of information for private forest owners - comparative analysis between Slovenia and BosniaHerzegovina. In: ŽIVOJINOVIĆ, I. et al. (ed): Concepts, methods and findings in forest ownership research in Europe. Mid-term Proceedings of the COST Action FP1201 Forest Land Ownership Changes in Europe: Significance for Management and Policy, FACESMAP, EFICEEC-EFISEE Research Report. University of Natural Resources and Life Sciences, Vienna (BOKU), 37-44.

BANKOVIĆ, S., MEDAREVIĆ, M., PANTIĆ, D., PETROVIĆ, N. (2009): The National Forest Inventory of the Republic of Serbia - the growing stock of the Republic of Serbia. In: RANKOVIĆ, N. (ed), Ministry of Agriculture FaWMotRoS, Forest Directorate, Belgrade, pp 244.

BOON, T.E., MEILBY, H. (2007): Describing management attitudes to guide forest policy implementation. Small-scale Forestry 6(1), 79-92. 
BOON, TE., MEILBY, H. THORSEN, BJ. (2004): An Empirically Based Typology of Private Forest Owners in Denmark: Improving Communication Between Authorities and Owners. Scandinavian Journal of Forest Research 19(4), 45-55.

CORP, I. (2011): IBM SPSS Statistics for Windows. 20.0 edn. IBM Corp., Armon, New York.

EMtAge, N., HERBOHN, J., HARRISON, S. (2007): Landholder Profiling and Typologies for Natural Resource-Management Policy and Program Support: Potential and Constraints. Environmental Management 40(3), 481-492.

FIELD, A. (2009): Discovering statistics using SPSS. 3rd edn. SAGE, Los Angeles.

FINLEY, AO., KITTREDGE, DB., STEVENS, TH., SCHWEIK, CM., DENNIS, DC. (2006): Interest in cross-boundary cooperation: identification of distinct types of private forest owners. Forest Science 52, 10-22.

GLÜCK, P., AVDIBEgoVIĆ, M., ČABARAVDIĆ, A., NONIĆ, D., PETROVIĆ, N., POSAVEC, S., STOJANOVSKA, M. (2010): The preconditions for the formation of private forest owners' interest associations in the Western Balkan Region. Forest Policy and Economics 12(4), 250-263.

GLÜCK, P., AVDIBEgOVIĆ, M., ČABARAVDIĆ, A., NONIĆ, D., PETROVIĆ, N., POSAVEC, S., STOJANOVSKA, M. (2011): Private forest owners in the Western Balkans - Ready for the formation of interest associations. In: Hasenauer H (ed) EFI Research Report 25, Institute EF, Joensuu, Finland, pp 234.

HAMUNEN, K. et al. (2014): Defining Peer-to-peer Learning - from an Old 'Art of Practice' to a New Mode of Forest Owner Extension? The Journal of Agricultural Education and Extension 21(4), 293-307.

HOGL, K., PREGERNIG, M., WEISS, G. (2005): What is new about new forest owners? A typology of private forest ownership in Austria. Small-scale Forest Economics, Management and Policy 4(3), 325-342.

HOSMER, DW., LEMESHOW, S. (2000): Applied logistic regression. 2nd edn. John Wiley \& Sons, New York.

HUJALA, T., TIKKANEN, J. (2008): Boosters of and barriers to smooth communication in family forest owners' decision making. Scandinavian Journal of Forest Research 23(5), 466-477.

KARPPINEN, H. (1998): Values and Objectives of Non-industrial Private Forest Owners in Finland. Silva Fennica 32(1), 43-59.

KUULUVAINEN, J., KARPPINEN, H., OVASKAINEN, V. (1996): Landowner Objectives and Nonindustrial Private Timber Supply. Forest Science 42(3), 300309.

LEBAN, V. (2014): Efficiency analysis of forest owners associations in Slovenia and Germany. Master thesis, University of Ljubljana, Biotechnical Facutly, Department of Forestry and Renewable Forest Resources. 
LÖNNSTEDT, L. (1997): Non-industrial private forest owners' decision process: A qualitative study about goals, time perspective, opportunities and alternatives. Scandinavian Journal of Forest Research 12(3), 302-310.

MA, Z., KITTREDGE, D., CATANZARO, P. (2012): Challenging the Traditional Forestry Extension Model: Insights from the Woods Forum Program in Massachusetts. Small-scale Forestry 11(1), 87-100.

NI DHUBHÁIN, Á., COBANOVA, R., KARPPINEN, H., MIZARAITE, D., RITTER, E., SLEE, B., WALL, S. (2007): The Values and Objectives of Private Forest Owners and Their Influence on Forestry Behaviour: The Implications for Entrepreneurship. Small-scale Forestry 6(4), 347-357.

NI DHUBHÁIN, Á., MAGUIRE, K., FARELLY, N. (2010): The harvesting behaviour of Irish private forest owners. Forest Policy and Economics 12(7), 513-517.

PEZDEVŠEK MALOVRH, Š., (2010): Influence of institutions and forms of cooperation on private forest management. Doctoral dissertation, University of Ljubljana, Biotechnical Faculty, Department of Forestry and Renewable Forest Resources.

PEZDEVŠEK MALOVRH, Š., HODGES, DG., MARIĆ, B., AVDIBEGOVIĆ, M. (2011): Private forest owners expectations of interest associations: comparative analysis between Slovenia and Bosnia-Herzegovina. Šumarski list CXXXV(9-10):1-10.

PEZDEVŠEK MALOVRH, Š., NONIĆ, D., GLAVONJIĆ, P., NEDELJKOVIĆ, J., AVDIBEGOVIĆ, M., KRČ, J. (2015). Private Forest Owner Typologies in Slovenia and Serbia: Targeting Private Forest Owner Groups for Policy Implementation. Small-scale Forestry:1-18.

PEZDEVŠEK MALOVRH, Š., ZADNIK STIRN, L., KRČ, J. (2010): Influence of property and ownership conditions on willingness to cooperate. Šumarski list 134(3-4), 139-149.

RICKENBACH, M., ZEULI, K., STURGESS-CLEEK, E. (2005): Despite failure: The emergence of "new" forest owners in private forest policy in Wisconsin, USA. Scandinavian Journal of Forest Research 20(6), 503-513.

SCHMITHÜSEN, F., HIRSCH, F. (2010): Private forest ownership in Europe. In: (ed) Geneva Timber and Forest Study Paper 26, UNECE, Geneva, Switzerland, pp 110.

SCHUBERT, JR., MAYER, AL. (2012): Peer Influence of Non-Industrial Private Forest Owners in the Western Upper Peninsula of Michigan. Open Journal of Forestry 2(3), 150-158.

SMARS (2007): Relational databases from the Landowner register. Ljubljana.

WIERSUM, KF., ELANDS, BM., HOOGSTRA, M. (2005): Small-scale forest ownership across Europe: Characteristics and future potential. Small-scale Forest Economics, Management and Policy 4(1), 1-19. 
ZIEGENSPECK, S., HÄRDTER, U., SCHRAML, U. (2004): Lifestyles of private forest owners as an indication of social change. Forest Policy and Economics 6(5), 44745.

ŽIVOJINOVIĆ, I. et al. (2015): Forest Land Ownership Change in Europe. COST Action FP1201 FACESMAP Country Reports.

\section{SAŽETAK}

Mnogobrojne promjene u državama jugoistočne Evrope uslovile su značajne izmjene u obrascima nacionalnih šumarskih politika, kreirajući potpuno novu paradigmu po pitanju šumarstva i gospodarenja šumskim resursima. To je, između ostalog, dovelo i do povećanja heterogenosti vlasnika privatnih šuma, koja se ogleda u promjenama u njihovim očekivanjima, ciljevima, stavovima i aktivnostima gospodarenja. U tom kontekstu je interesantno istražiti kako vlasnici privatnih šuma prikupljaju informacije korisne za gospodarenje, ali takođe i analizirati na koji način karakteristike vlasnika utiču na zadovoljenje potreba za informacijama. Ovaj rad je imao za cilj da analizira izvore informacija koje vlasnici privatnih šuma najčešće koriste, te da se utvrdi kako karakteristike vlasnika i njihovog šumoposjeda, te intenzitet i način gospodarenja utiču na izbor izvora informacija. Istraživanje je provedeno u Bosni i Hercegovini, Srbiji, Hrvatskoj (u sve tri države je broj ispitanika bio po 350) i Sloveniji (broj ispitanika je bio 322), na slučajno izabranom uzorku vlasnika privatnih šuma. Dobijeni podaci su analizirani korištenjem modela logističke regresije. U radu je analizirano sljedećih pet modela izvora informacija: udruženja vlasnika privatnih šuma (1), rođaci (2), javna šumarska administracija (3), ostali vlasnici privatnih šuma (4) i javna šumarska preduzeća (5). Kad su u pitanju izvori informacija, uočene razlike po državama su uglavnom uzrokovane važnošću šuma za njihove vlasnike i različitom organizacijom nacionalnih sektora šumarstva. U poređenju sa drugim analiziranim državama, vlasnici privatnih šuma u Sloveniji su znatno aktivniji u traganju za informacijama. Javna šumarska administracija je najčešći izvor informacija za vlasnike u Sloveniji, dok su u Bosni i Hercegovini, pored javne šumarske administracije, najčešći izvor informacija javna šumarska preduzeća. U Srbiji i Hrvatskoj su to takođe šumarska preduzeća. Udruženja vlasnika privatnih šuma su identificirana kao izvor informacija jedino u Sloveniji. Tradicionalni izvori informacija (npr. ostali vlasnici privatnih šuma) su još uvijek važni u Sloveniji i Bosni i Hercegovini. Veličina i usitnjenost posjeda, intenzitet gospodarenja i životna dob vlasnika utiču na izbor izvora informacija. Model logističke regresije "javna šumarska administracija" je statistički značajan u Bosni i Hercegovini i Sloveniji, dok je model "javno šumarsko preduzeće" značajan u Srbiji i Bosni i Hercegovini. Nijedan od pet analiziranih modela nije statistički značajan u Hrvatskoj. U Sloveniji je značajan još i model "ostali vlasnici privatnih šuma". Rezultati ovih ustraživanja ukazuju na važnu ulogu javne šumarske administracije i šumarskih preduzeća kao ključnih izvora 
korisnih informacija za vlasnike privatnih šuma. Ne zanemarujući ulogu tradicionalnih izvora, kao što su susjedi, rođaci i drugi vlasnici, evidentno je da postoji veliki potencijal u kreiranju asocijacija privatnih šumoposjednika kao izvora informacija. Rezultati ranijih istraživanja ukazuju na postojanje kritične mase vlasnika privatnih šuma za formiranje takvih asocijacija. S obzirom da su vlasnici privatnih šuma $u$ analiziranim državama jugoistočne Evrope, prilično heterogena skupina, javna šumarska administracija treba razviti i implementirati miks instrumenata šumarske politike koji bi na najbolji način zadovoljio specifične interese različitih tipova vlasnika. S obzirom da informacioni instrumenti šumarske politike, kao što su savjetodavna služba, mašinski krugovi, edukacija i sl., nisu u dovoljnoj mjeri razvijeni u analiziranim državama (izuzetak je donekle Slovenija), postoje značajne mogućnosti za njihovu primjenu, a samim tim i unaprijeđenje nacionalnih šumarskih politika u smislu boljeg zadovoljenja potreba vlasnika privatnih šuma za informacijama. 